Tohoku J. exp. Med., 1965, 85, 72-82

\title{
Calcium Movement in the Smooth Muscle of Guinea-pig Taenia Coli
}

\author{
By \\ Jeunichiro Nagasawa \\ From the Department of Applied Physiology, Tohoku University School \\ of Medicine, Sendai
}

(Received for publication, September 28, 1964)

\begin{abstract}
The movement of calcium ions in the smooth muscle of guinea-pig taenia coli under various conditions was estimated by means of radioisotope technique. Uptake of ${ }^{45} \mathrm{Ca}$ was not affected by the temperature of the soaking Krebs solution, whereas the rate of efflux of ${ }^{45} \mathrm{Ca}$ decreased considerably in low temperature Krebs solution. Ethylenediamine-tetraacetate (EDTA) increased not only the rate of loss of ${ }^{45} \mathrm{Ca}$ but also influenced markedly the movements of sodium and potassium ions in this tissue; after 30 minutes' incubation in $4 \mathrm{mM}$ EDTA-Krebs solution, taenia coli lost about $60 \mathrm{~m}$-mole/ $/ \mathrm{kg}$ wet wt. potassium and gained $55 \mathrm{~m}-\mathrm{mole} / \mathrm{kg}$ wet wt. sodium. Depolarization by high potassium, application of adrenaline, histamine or serotonin increased the efflux of calcium, but the effect of acetylcholine was variable dependent on the state of muscle preparation.
\end{abstract}

The importance of calcium ions as the link between the electrical and contractile activity of the muscle has been well observed both in skeletal ${ }^{1,2}$ and in cardiac muscles. ${ }^{3,4}$ Recent evidences suggest that this could also hold for smooth muscle preparations.

In frog skeletal muscle, Bianchi and Shanes ${ }^{1}$ studied the uptake of tracer ${ }^{45} \mathrm{Ca}$, and concluded that calcium uptake increased during electrical stimulation or potassium induced contracture and the increased calcium thus taken up by the muscle originated from sites on the surface of the muscle fiber to which calcium was preliminary bound. ${ }^{45} \mathrm{Ca}$ efflux of the frog skeletal muscle was also reported to be increased during electrical stimulation and potassium induced contracture. 5

In smooth muscle, however, no clear evjdence has appeared concerning the movements of calcium ions during electrical stimulation or potassium induced contracture.

The experiments described here were designed to investigate the movement of ${ }^{45} \mathrm{Ca}$ in the smooth muscle of guinea-pig taenia coli under various conditions

長沢純一郎 
such as low temperature Krebs solution, calcium free Krebs solution and high potassium Krebs solution. The increase of ${ }^{45} \mathrm{Ca}$ efflux was clearly demonstrated in both potassium induced contracture and in contractures produced by the applciation of several smooth muscle stimulants such as histamine, serotonin and adrenaline.

\section{METHODS}

All the experiments were performed on the smooth muscle preparation of guinea-pig taenia coli. The modified Krebs-Ringer solution used in these experiments had the following composition (mM), $\mathrm{NaCl} 155.0, \mathrm{KCl} 3.4, \mathrm{CaCl}_{2} 1.8$, $\mathrm{MgCl}_{2} 0.25, \mathrm{NaHCO}_{3} 1.0, \mathrm{NaHPO}_{4} 2.0$, glucose 5.6 and was bubbled with oxygen.

For preparation of EDTA-Krebs solution, $4.0 \mathrm{mM}$ EDTA-2Na (disodium. ethylenediamine-tetraacetate) was added to the calcium and magnesium free Krebs solution.

The tracer ${ }^{45} \mathrm{Ca}$ was obtained from Oak Ridge National Laboratory, U.S.A. as ${ }^{45} \mathrm{CaCl}_{2}$ in $\mathrm{HCl}$ solution ( $\left.{ }^{45} \mathrm{Ca}-\mathrm{P}-2\right)$, and was neutralized with $\mathrm{NaOH}$ before use. To make up ${ }^{45} \mathrm{Ca}-\mathrm{Krebs}$ solution, the tracer dose of this ${ }^{45} \mathrm{Ca}$ solution was added to the normal Krebs solution. Final strength of the radioactivity of this ${ }^{45} \mathrm{Ca}$ Krebs solution was between 5 to $20 \mu \mathrm{c} / \mathrm{ml}$.

The basic methods for measurements of ${ }^{45} \mathrm{Ca}$ and ${ }^{42} \mathrm{~K}$ activity and the muscle electrolytes were essentially the same as those described previously, ${ }^{6}$ but owing to the very weak $\beta$-emission of ${ }^{45} \mathrm{Ca}$, it was soon found not proper to determine the ${ }^{45} \mathrm{Ca}$ activity with the whole strip mounted on a glass frame as described before. For instance, the successive 1 minute's counting of the same strip by usual way gave the progressive increase of counting number up to $10 \%$ perhaps due to the evaporation of surface water of the tissue. So in the later stage of experiments, the counting was performed as a rule by the proportional gas flow counter on the dried materials. The samples were carefully prepared and corrected for self-absorption by solid materials and salts. In this experiment, correction for the decay of ${ }^{45} \mathrm{Ca}$ was not performed, for the half-life of ${ }^{45} \mathrm{Ca}$ is sufficiently long (152 days) as compared to the duration of experimental periods.

\section{RESULTS}

\section{Effect of temperature on the movement of ${ }^{45} \mathrm{Ca}$}

The preliminary experiments were performed in the usual successive "soak in, soak out" type to get the rough idea of the ${ }^{45} \mathrm{Ca}$ movement in the taenia coli, though the results contain much variability as already described in the methods section.

The uptake of ${ }^{45} \mathrm{Ca}$ (Fig. 1) was not much affected by the temperature of soaking solution. Both at $37^{\circ} \mathrm{C}$ and $20^{\circ} \mathrm{C}$, the uptake curve reached an apparent equilibrium about $150 \mathrm{~min}$ after immersion in ${ }^{45} \mathrm{Ca}-\mathrm{Krebs}$ solution. In this 


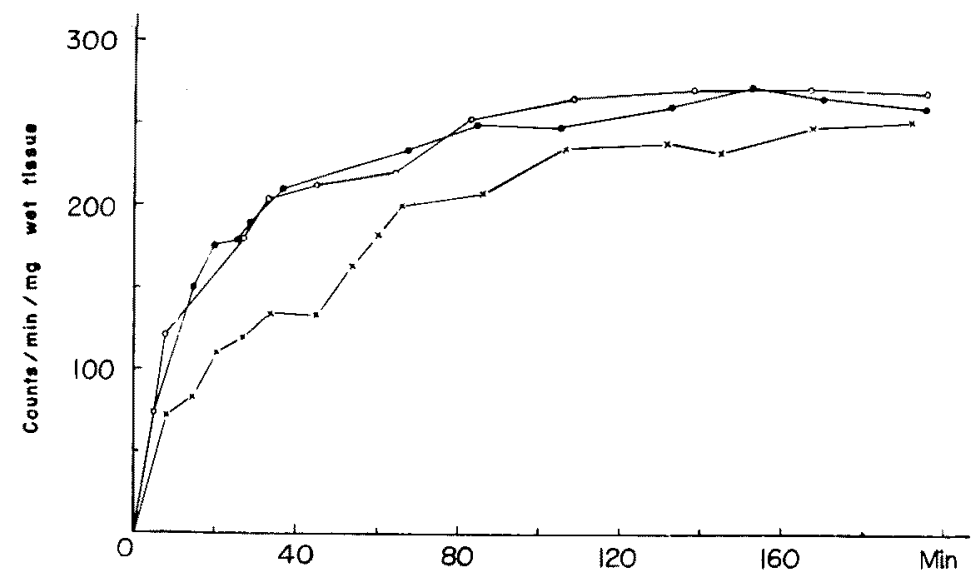

Fig. 1. Effect of temperature on the uptake of ${ }^{45} \mathrm{Ca}$ in taenia coli. $37^{\circ} \mathrm{C}$ (open circle), $20^{\circ} \mathrm{C}$ (solid circle), $2^{\circ} \mathrm{C}$ (cross marks). Taeniae were immersed exactly $1 \mathrm{~min}$ in inactive Krebs solution and lightly blotted before each counting. Calcium concentration $1.8 \mathrm{mM}, 1 \mathrm{cpm}$ corresponds $6.93 \times 10^{-\theta}$ m-mole calcium.

equilibrium, the caleium concentration of the taenia coli calculated from the ${ }^{45} \mathrm{Ca}$ activity was $1.79 \mathrm{~m}-\mathrm{mole} / \mathrm{kg}$ wet wt., and was not greatly different from the calcium concentration of soaking Krebs solution $(1.8 \mathrm{mM})$.

The time course of loss of ${ }^{45} \mathrm{Ca}$ in inactive Krebs solution (Fig. 2) was more

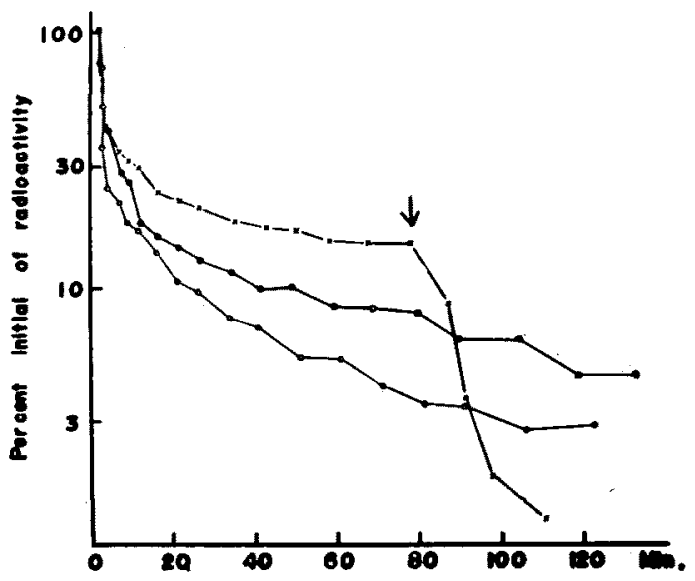

Fig. 2. Effect of temperature on the loss of ${ }^{45} \mathrm{Ca}$ from taenia coli, which were preloaded in ${ }^{45} \mathrm{Ca}$-Krebs solution for $210 \mathrm{~min} .37^{\circ} \mathrm{C}$ (open circle), $20^{\circ} \mathrm{C}$ (solid circle), $4^{\circ} \mathrm{C}$ (cross marks). At an arrow, the taenia which had been immersed in $4^{\circ} \mathrm{C}$ inactive Krebs solution was transferred to $37^{\circ} \mathrm{C}$ Krebs solution. Ordinate, relative ${ }^{46} \mathrm{Ca}$ activity remained in the musele; abscissa, time in inactive Krebs solution. 
temperature dependent than uptake and the values obtained could not be plotted on a straight line even in a semi-logarithmic co-ordinate; suggesting, at least, two components must be considered as the source of this ${ }^{45} \mathrm{Ca}$ efflux. But it was impossible to determine the exact time constants for these components because the estimated points scattered in wide range. In spite of this, it is clearly shown in the graph that in higher temperature solution the radioactivity decreases more rapidly. At $4^{\circ} \mathrm{C}$, the slow component of the efflux curve showed no further decrease after about $60 \mathrm{~min}$ of immersion, but when the temperature of this solution was raised up to $37^{\circ} \mathrm{C}$, the residual ${ }^{45} \mathrm{Ca}$ in the muscle decreased rapidly. This result agrees well with the mode of sodium exchange already reported, ${ }^{6}$ and might suggest the existence of the temperature dependent active calcium extrusion mechanism or calcium pump in this tissue as suggested by Schatzmann.?

The effect of low calcium Krebs solution or high potassium Krebs solution on the ${ }^{45} \mathrm{Ca}$ efflux was also investigated in the course of this experiment, but the small difference of the efflux rates in these solutions fell into the range of the counting error, and no definite conclusion could be obtained.

\section{Effect of EDTA on the movement of ${ }^{45} \mathrm{Ca}, \mathrm{K}$ and $\mathrm{Na}$}

EDTA-2Na is a strong chelating agent and its action to combine with the bivalent metal ions has been often used in the field of muscle physiology to elucidate

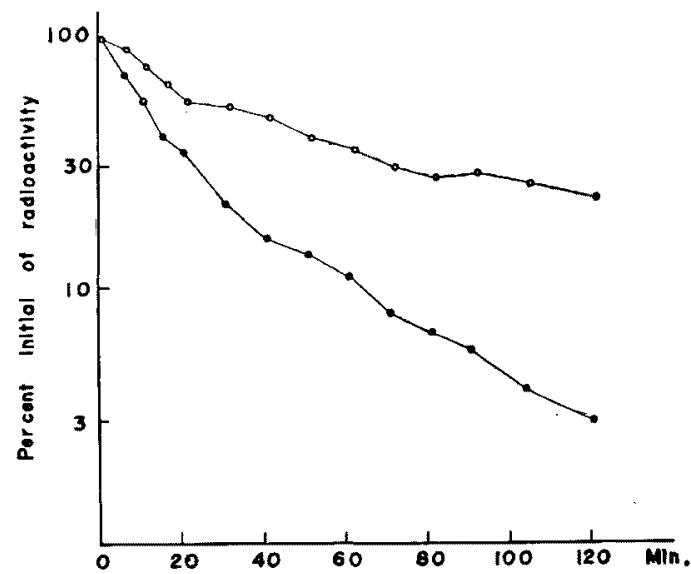

Fig. 3. Effect of EDTA-2Na on the loss of ${ }^{45} \mathrm{Ca}$ from taenia coli at $37^{\circ} \mathrm{C}$. Normal Krebs solution (open circle), $4 \mathrm{mM}$ EDTA-Krebs solution (solid circle). Both strips were preloaded in ${ }^{45} \mathrm{Ca}$-Krebs solution for 170 min, washed out for $60 \mathrm{~min}$ in inactive $\mathrm{Krebs}$ solution at $2^{\circ} \mathrm{C}$ before the experiment.

the action of calcium and magnesium ions on the cell membrane and contractile proteins in the muscle..$^{8,9}$

The effect of acute calcium deprivation from soaking solution was studied by 
adding EDTA to the soaking solution. In this experiment, the preloaded taeniae were washed for $60 \mathrm{~min}$ in inactive Krebs solution before the onset of experiment and the results refer more directly to the movement of intracellular calcium than the case illustrated in Fig. 2.

The loss of ${ }^{45} \mathrm{Ca}$ increased clearly in $4 \mathrm{mM}$ EDTA-Krebs solution; the half-

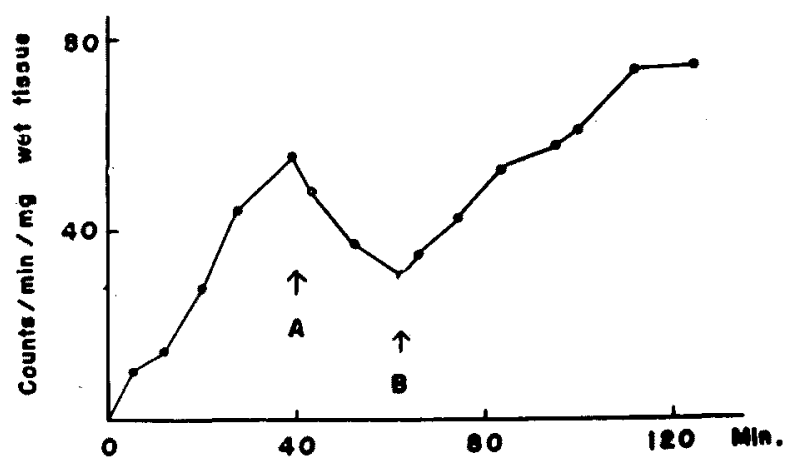

Fig. 4. Effect of EDTA-2Na on the uptake of ${ }^{42} \mathrm{~K}$. At $\mathrm{A}, 4 \mathrm{mM}$ EDTA was added to ${ }^{42} \mathrm{~K}-\mathrm{K}$ rebs solution and at $\mathrm{B}, 5 \mathrm{mM} \mathrm{CaCl} \mathrm{Cl}_{2}$ was added to the same solution. Potassium concentration of soaking Krebs solution was $4.4 \mathrm{mM}$ and $1 \mathrm{cpm}$ corresponds $3.36 \times 10^{-7} \mathrm{~m}$-mole potassium. Temperature $37^{\circ} \mathrm{C}$.

time of decrease was about $55 \mathrm{~min}$ in normal Krebs solution and $25 \mathrm{~min}$ in EDTAKrebs solution.

In the same experimental conditions, we could not find any appreciable change in the rate of loss of ${ }^{45} \mathrm{Ca}$ from the taenia coli immersed in low calcium Krebs solution where no EDTA was present.

Fig. 4 shows the effect of EDTA on the ${ }^{42} \mathrm{~K}$ uptake. When $4 \mathrm{mM}$ EDTA was added to the ${ }^{42} \mathrm{~K}-\mathrm{K}$ rebs solution about $40 \mathrm{~min}$ after the onset of uptake experiment, it caused a rapid decrease of ${ }^{42} \mathrm{~K}$ content of the tissue. The ${ }^{42} \mathrm{~K}$ content decreased $55.5 \%$ of the initial value during $23 \mathrm{~min}$ in EDTA solution, suggesting EDTA should cause a large outward movement of potassium. The effect was also clearly demonstrated in the efflux experiment of ${ }^{42} \mathrm{~K}$ (Fig. 5), where the half-times of loss of ${ }^{42} \mathrm{~K}$ were $45 \mathrm{~min}$ in normal Krebs solution and $7 \mathrm{~min}$ in EDTA-Krebs solution. Decreased ${ }^{42} \mathrm{~K}$ content caused by EDTA was recovered by the addition of $5 \mathrm{mM} \mathrm{CaCl}_{2}$ to this solution (Fig. 4), thus the action of EDTA could be reversed in part by the calcium ions only. Low calcium Krebs solution showed no such drastic effect upon the movement of potassium.

The potassium and sodium contents of the taenia coli after $30 \mathrm{~min}$ in EDTAKrebs solution were $\mathrm{Na}=137.4 \pm 9.05$ and $\mathrm{K}=17.3 \pm 6.70 \mathrm{~m}$-mole $/ \mathrm{kg}$ wet wt., the corresponding values in normal Krebs solution were $\mathrm{Na}=82.1 \pm 7.14$ and $\mathrm{K}=$ $77.9 \pm 8.31 \mathrm{~m}$-mole $/ \mathrm{kg}$ wet $\mathrm{wt}$. respectively. Thus there was about $60 \mathrm{~m}$-mole/ 


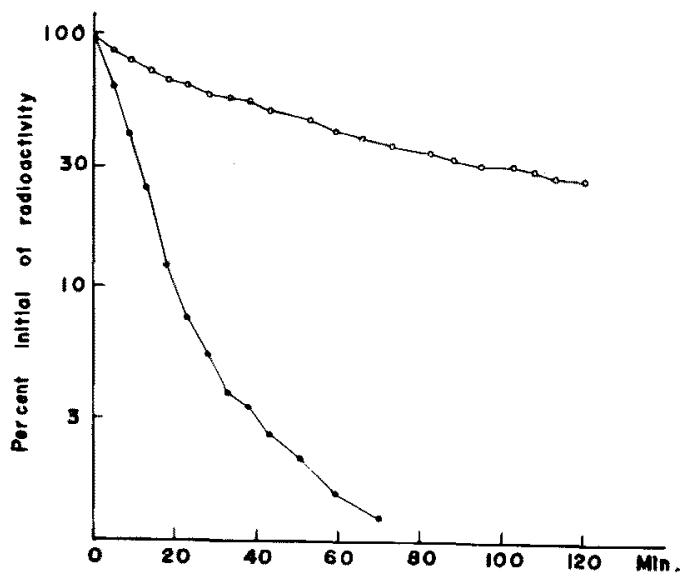

Fig. 5. Loss of ${ }^{42} \mathrm{~K}$ in normal Krebs solution (open circle) and in $4 \mathrm{mM}$ EDTA-Krebs solution (solid circle). Taeniae had been preloaded for 120 $\min$ in ${ }^{42} \mathrm{~K}$-Krebs solution before the experiment. Temperature $37^{\circ} \mathrm{C}$.
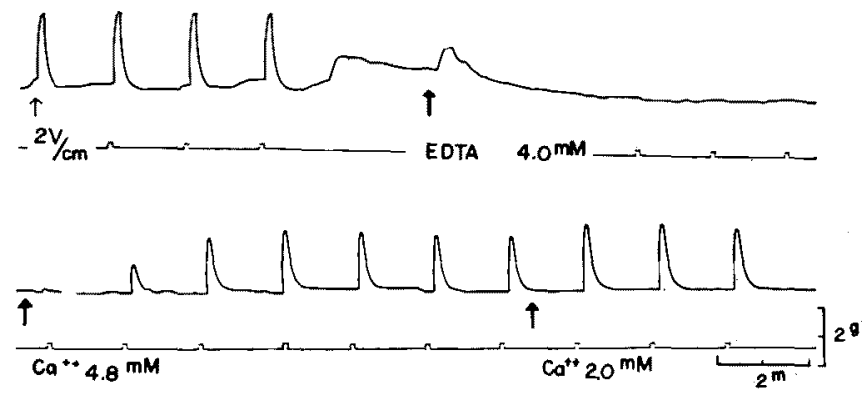

Fig. 6. Effect of EDTA-2Na on the contractile response of taenia coli by electrical stimulation $(2 \mathrm{~V} / \mathrm{cm}, 50 \mathrm{c} / \mathrm{s}$, a.c.) which was given for 5 seconds at intervals of 90 seconds. When $4 \mathrm{mM}$ EDTA was applied, taenia, after a transient spontaneous contraction, became silent. Note the rapid restoration of contraction following the administration of $4.8 \mathrm{mM}$ $\mathrm{CaCl}_{2}$ into the solution. Recovery seems complete after further $2.0 \mathrm{mM}$ $\mathrm{CaCl}_{2}$. Temperature $37^{\circ} \mathrm{C}$.

$\mathrm{kg}$ wet wt. of potassium loss and $55 \mathrm{~m}$-mole $/ \mathrm{kg}$ wet wt. of sodium gain during this period, and these results agree well with the tracer experiments described above.

The action of EDTA on the contractile response of taenia coli is shown in Fig. 6. EDTA suppressed rapidly the spontaneous contraction and contractions induced by electrical stimulations, but they reappeared in a few minutes after the addition of $\mathrm{CaCl}_{2}$ to the bathing solution. The recovery of contractile response by $\mathrm{CaCl}_{2}$ in this case seems to occur more rapidly than the restoration of the distribution of sodium and potassium ions across the cell membrane. 
Effect of depolarization on the efflux of ${ }^{45} \mathrm{Ca}$

The change of ${ }^{45} \mathrm{Ca}$ efflux in high potassium solution was studied by the successive immersion method. As illustrated in Figs. 7 and 8 , high potassium

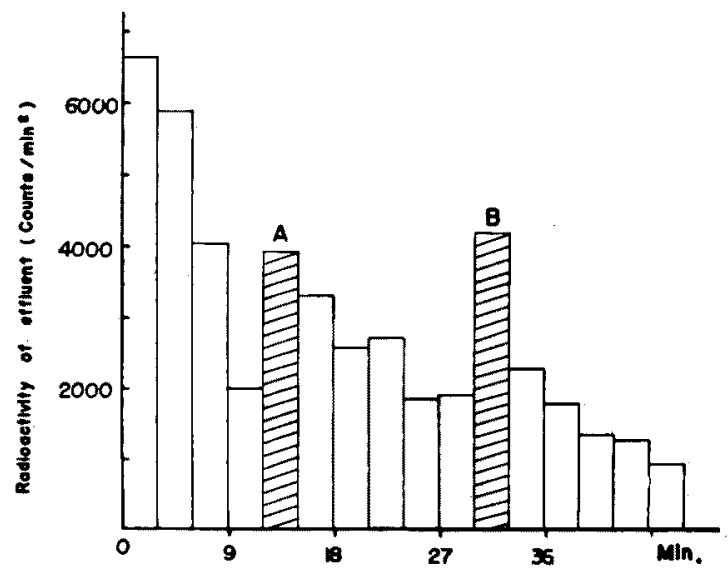

Fig. 7. Effect of $\mathrm{KCl}$ depolarization on the efflux of ${ }^{45} \mathrm{Ca}$. Each column shows the activity of ${ }^{45} \mathrm{Ca}$ emerged in $2 \mathrm{ml}$ washing solution during 3 min immersion. At $A$, normal soaking Krebs solution was replaced with $85 \mathrm{mM} \mathrm{KCl-Krebs} \mathrm{solution} \mathrm{and} \mathrm{at} \mathrm{B,} \mathrm{normal} \mathrm{Krebs} \mathrm{solution} \mathrm{was}$ replaced with $170 \mathrm{mM}$ KCl-Krebs solution. Taenia had been preloaded for $120 \mathrm{~min}$ in ${ }^{45} \mathrm{Ca}$-Krebs solution and washed in inactive Krobs solution for $45 \mathrm{~min}$ before the experiment. Temperature $37^{\circ} \mathrm{C}$. All through Figs. 7 to $12,1 \mathrm{cpm}$ corresponds $6.46 \times 10^{-4} \mu \mu$-mol oalcium.

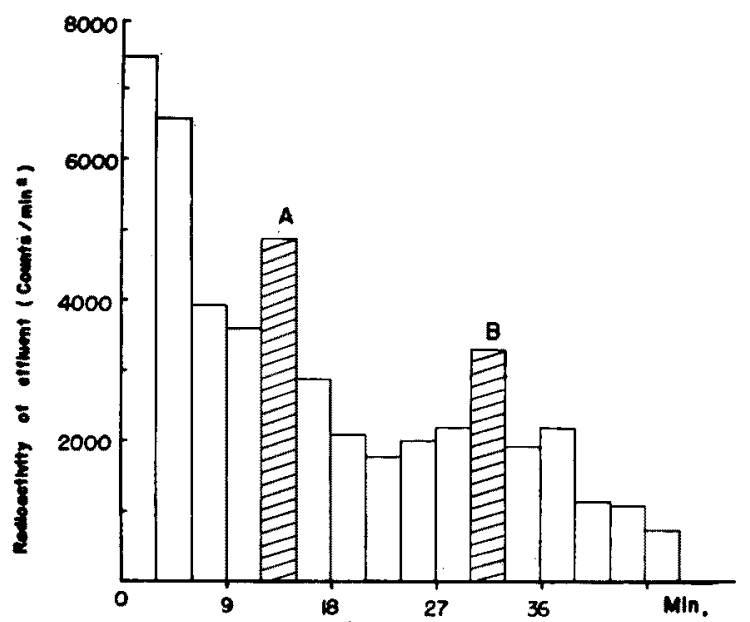

Fig. 8. Effect of $\mathrm{K}_{2} \mathrm{SO}_{4}$ depolarization on the efflux of ${ }^{45} \mathrm{Ca}$. At $\mathrm{A}$, normal Krebs solution was replaced with $42.5 \mathrm{mM} \mathrm{K}_{2} \mathrm{SO}_{4}$ - Krebs solution and at $\mathrm{B}, 85 \mathrm{mM} \mathrm{K} \mathrm{SO}_{4}-\mathrm{Krebs}$ solution. Taenia was similarly treated as in $\mathrm{KCl}$ depolarization. Temperature $37^{\circ} \mathrm{C}$. 
solutions either prepared by $\mathrm{KCl}$ or $\mathrm{K}_{2} \mathrm{SO}_{4}$ clearly increased the efflux of ${ }^{45} \mathrm{Ca}$. The increase of efflux was 1.4 times the mean efflux value by $85 \mathrm{mM} \mathrm{KCl}-\mathrm{Krebs}$ solution and 2.3 times by $170 \mathrm{mM} \mathrm{KCl-Krebs}$ solution, 1.3 times by $42.5 \mathrm{mM}$ $\mathrm{K}_{2} \mathrm{SO}_{4}$-Krebs and 1.8 times by $85 \mathrm{mM} \mathrm{K} \mathrm{SO}_{4}$-Krebs solution.

Effect of drugs on the efflux of ${ }^{45} \mathrm{Ca}$

The change of efflux of ${ }^{45} \mathrm{Ca}$ by the application of various smooth muscle stimulant drugs were examined. The drugs used were histamine, serotonin, acetylcholine and adrenaline, they were applied to the same strip two times with

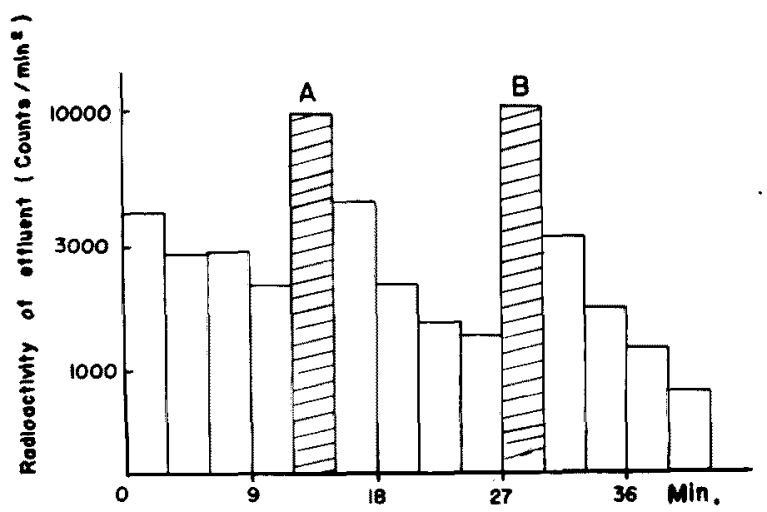

Fig. 9. Effect of histamine on the ${ }^{45} \mathrm{Ca}$ efflux. At $\mathrm{A}, 1 \times 10^{-4}$ at $\mathrm{B}, 1 \times$ $10^{-3} \mathrm{~g} / \mathrm{ml}$ histamine was applied for $3 \mathrm{~min}$. Taenia had been preloaded for $120 \mathrm{~min}$ in ${ }^{45} \mathrm{Ca}-\mathrm{Krebs}$ solution and washed in inactive Krebs solution for $60 \mathrm{~min}$ before the experiments. Increments of efflux were at A, 3.9 at $\mathrm{B}, 7.1$ times the average efflux. Temperature $37^{\circ} \mathrm{C}$.

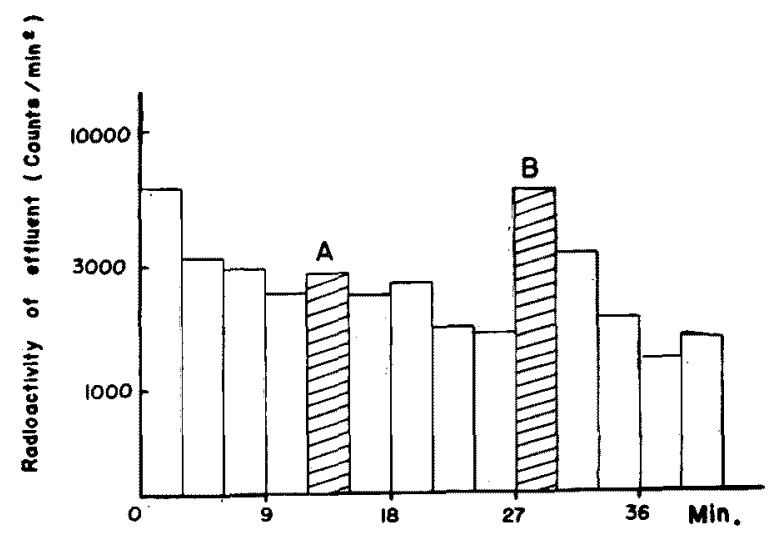

Fig. 10. Effect of serotonin on the ${ }^{45} \mathrm{Ca}$ efflux. At $\mathrm{A}, 5 \times 10^{-5}$ at $\mathrm{B}$, $2.5 \times 10^{-4} \mathrm{~g} / \mathrm{ml}$ serotonin was applied for $3 \mathrm{~min}$. Increments of efflux were at $A, 1.2$ at $B, 3.5$ times the average efflux. 
different concentrations to confirm the reproducibility of the results (Figs. 9 to 12).

Histamine and serotonin had always increased the rate of efflux of ${ }^{45} \mathrm{Ca}$. But the action of acetylcholine was different, the efflux of ${ }^{45} \mathrm{Ca}$ in this case seems to be governed by the condition of muscle preparation or the amount of acetylcholine applied and other as yet unknown factors. Fig. 11 is a case, where acetylcholine showed most dominant increasing effect on ${ }^{45} \mathrm{Ca}$ efflux but in some cases,

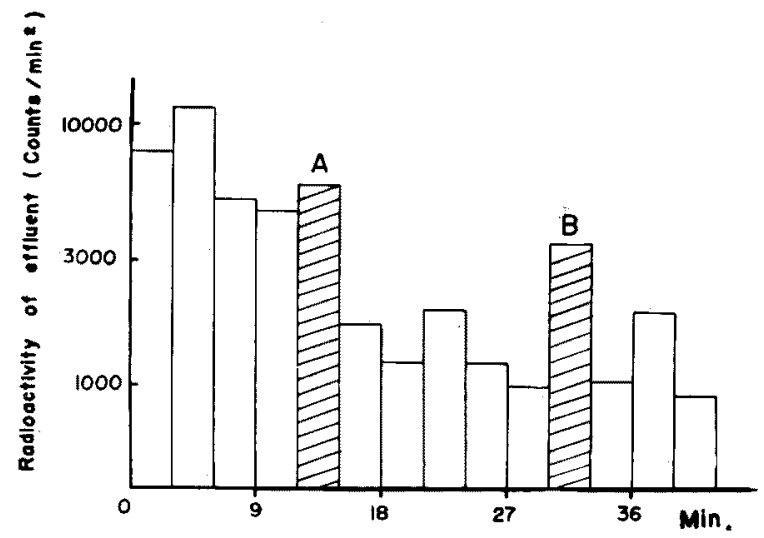

Fig. 11. Effect of acetylcholine on the ${ }^{45} \mathrm{Ca}$ efflux. At $\mathrm{A}, 1 \times 10^{-4}$ at $\mathrm{B}, 1 \times 10^{-3} \mathrm{~g} / \mathrm{ml}$ acetyloholine was applied for $3 \mathrm{~min}$. Increments of efflux were at $A, 1.2$ at $B, 3.2$ times the average efflux.

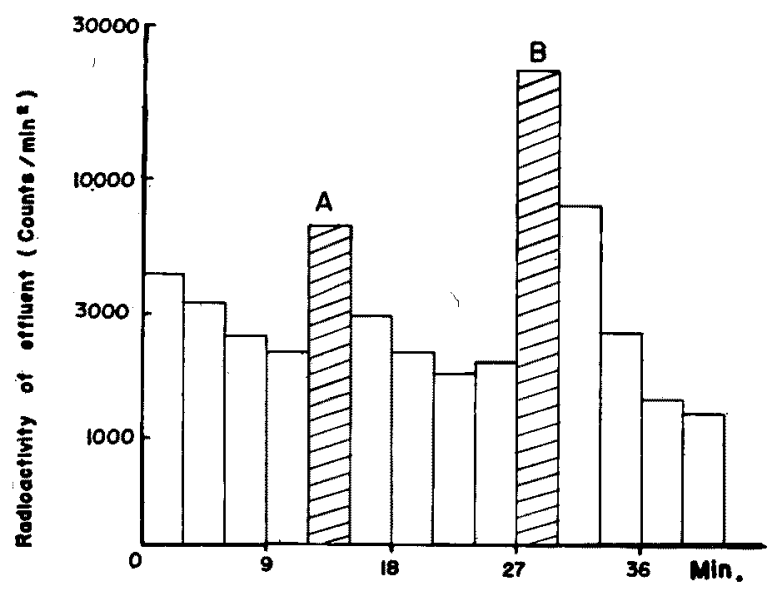

Fig. 12. Effect of adrenaline on ${ }^{45} \mathrm{Ca}$ efflux. At $\mathrm{A}, 1 \times 10^{-4}$ at $\mathrm{B}, 1 \times$ $10^{-3} \mathrm{~g} / \mathrm{ml}$ adrenaline was applied for $3 \mathrm{~min}$. Increments of efflux were at A, 2.9 at B, 14.3 times the average efflux.

efflux was unchanged, in others, it was decreased and sometimes larger dose of acetylcholine rather depressed the efflux of ${ }^{45} \mathrm{Ca}$. 
Adrenaline, which causes the taenia to relax, also produced the marked increase of the efflux of ${ }^{45} \mathrm{Ca}$ (Fig. 12).

\section{DISCUSSION}

The present experiments on the ${ }^{45} \mathrm{Ca}$ exchange in taenia coli revealed that ${ }^{45} \mathrm{Ca}$ uptake at $37^{\circ} \mathrm{C}$ reached an apparent equilibrium after about 150 minutes' incubation in ${ }^{45} \mathrm{Ca}$-Krebs solution, and the amount of ${ }^{45} \mathrm{Ca}$ taken up in the muscle, that is, exchangeable calcium of the taenia coli was not greatly different from the calcium concentration of the soaking Krebs solution. This finding confirms the result of Schatzmann ${ }^{7}$ who reported that taenia coli contains the exchangeable calcium as roughly the same amount as the calcium concentration of the external fluid, except about $3 \mathrm{~m}$-mole/kg wet wt. of tissue bound calcium which was not extractable even after 1 hour's immersion in calcium free solution.

We were unable to determine the exact time constants of the loss of ${ }^{45} \mathrm{Ca}$ in the taenia coli, because the degree of exchange between tissue bound calcium with ${ }^{45} \mathrm{Ca}$ of the soaking solution could not be decided exactly when the preloading was over. Actually, Durbin and Jenkinson, ${ }^{10}$ in the depolarized taenia coli, found difference of the configuration of the wash-out curves of ${ }^{45} \mathrm{Ca}$, depending on the duration of the preloading time in radioactive calcium solution.

It was found that EDTA affects not only the movement of calcium but also strongly modifies the movements of both potassium and sodium ions in the taenia coli. After 30 minutes' incubation in $4 \mathrm{mM}$ EDTA-Krebs solution, taenia coli had lost about $60 \mathrm{~m}$-mole $/ \mathrm{kg}$ wet wt. potassium and had gained $55 \mathrm{~m}-\mathrm{mole} / \mathrm{kg}$ wet wt. sodium, and these movements were almost completely reversible by the addition of calcium ions in the solution. Such a drastic change in ionic composition could not be observed in low calcium Krebs solution. One of the possible explanations of this remarkable ionic movements is as follows, the calcium and magnesium free environment as a result of EDTA application impairs the membrane activity to extrude sodium and keep potassium inside, perhaps due to in part reversible destruction of membrane structure following the deprivation of membrane bound calcium. And it seems that low calcium Krebs solution alone is not sufficient to deprive this membrane bound calcium or it needs more time to affect the membrane structure. Thus membrane bound or near the membrane site calcium seem to play an essential part in regulating the membrane activity of sodium transport mechanism.

The contractile response of taenia coli instantaneously disappeared when EDTA was applied to the bathing solution (Fig. 6). By this time, potassium content of the taenia coli might remain still low as judged from the recovery curve of ${ }^{42} \mathrm{~K}$ content (Fig. 4). Then the generation of contraction in taenia coli seems to be only dependent on the presence of calcium ions around the muscle cell and the need for potassium is not critical. 
In frog skeletal muscle, efflux of calcium was reported to increase by the electrical stimulation and potassium induced contracture. ${ }^{5}$ The present results revealed that the potassium depolarization also increased the efflux of calcium in the smooth muscle of taenia coli. Histamine, serotonin and adrenaline also increased the calcium efflux of the tissue, but the action of acetylcholine seemed to be different from others. Durbin and Jenkinson, 10 reported that calcium efflux of depolarized taenia coli was increased by the application of carbachol (carbaminoylcholine chloride) though it was not so much significant as compared to the increase of potassium effux. Schatzmann 7 reported that calcium efflux of taenia coli increased $53 \%$ by 30 minutes' application of $100 \mathrm{mM} \mathrm{KCl}$, but $1 \times 10^{-5}$ $\mathrm{g} / \mathrm{ml}$ acetylcholine had no such recognizable effect. Thus the action of acetylcholine on the calcium efflux seems to be variable in this tissue, though it is the most strong agent to increase the potassium efflux of this tissue. ${ }^{6}$

Edman and Schild ${ }^{11}$ studied the mechanism of the potassium and acetylcholine contractures of the depolarized rat uterus, concluded that acetylcholine should have to release the bound calcium in the muscle and thus initiate contractures. If the situation is the same in taenia coli, the present results will be explained as follows, that 1) the greater part of free ${ }^{45} \mathrm{Ca}$ in the muscle disappeared from intracellular compartment early during preliminary washing, and 2) the calcium released by the acetylcholine originated from tissue bound site, where they were not fully replaced with ${ }^{45} \mathrm{Ca}$ during initial preloading period, (owing to the firm binding with substrates in the muscle such as ATP or contractile proteins) and the resultant increase of calcium efflux could not be detected as the increase of radioactive calcium. But the limited data permit no further discussion on this problem and await more detailed experiments.

\section{Acknowledgment}

This work was suggested by Professor Taizo Suzuki and was supported in part by the Grant of the Population Council to him.

\section{References}

1) Bianchi, C.P. \& Shanes, A.M. J. gen. Physiol., 1959, $42,803$.

2) Frank, G.B. J. Physiol. (Lond.), 1960, 151, 518.

3) Niedergerke, R. ibid., 1956, 134, 584.

4) Lüttgau, H.C. \& Niedergerke, R. ibid., 1958, 143, 486.

5) Shanes, A.M. \& Bianchi, C.P. J. gen. Physiol., 1960, 43, 481.

6) Nagasawa, J. Tohoku J. exp. Med., 1963, 81, 222.

7) Schatzmann, H.J. Pfiügers. Arch. ges. Physiol., 1961, 274, 295.

8) Gilbert, D.L. \& Fenn, W.O. J. gen. Physiol., 1957, 40, 393.

9) Ebashi, S. J. Biochem. (Tokyo), 1960, 38, 150.

10) Durbin, R.P. \& Jenkinson, D.H. J. Physiol. (Lond.), 1961, 157, 74.

11) Edman, K.A.P. \& Schild, H.O. ibid., 1962, 161, 424. 